\title{
Pengembangan Lembar Kerja Peserta Didik Berbasis Realistic Mathematics Education dengan Konteks Kemaritiman untuk Peserta Didik SMA Kelas XI
}

\author{
Maimunah $^{1^{*}}$, Nur Izzati ${ }^{2}$, Alona Dwinata ${ }^{3}$ \\ ${ }^{123}$ Universitas Maritim Raja Ali Haji, Kota Tanjungpinang, Provinsi Kepulauan Riau 29122, Indonesia
}

Pengiriman: 2 September 2019; Diterima: 23 Oktober 2019; Publikasi: 30 Oktober 2019

DOI: https://doi.org/10.31629/jg.v4i2.1530

\begin{abstract}
Abstrak
Kurangnya penggunaan bahan ajar yang mampu membantu peserta didik untuk memahami pembelajaran matematika disekolah menyebabkan pencapaian kecakapan matematika peserta didik masih dalam kategori rendah. Tujuan penelitian untuk mengembangkan Lembar Kerja Peserta Didik (LKPD) berbasis Realistic Mathematics Education (RME) dengan konteks kemaritiman yang valid, praktis dan efektif. Penelitian ini berjenis Research and Development (R\&D) dengan model pengembangan ADDIE yang terbatas yaitu tahap Analysis, Design, Development (ADD). Data dalam penelitian dikumpulkan dengan metode tes dan angket. Instrumen penelitian yang digunakan yaitu lembar validasi ahli, lembar angket respon peserta didik, serta lembar tes. Data dianalisis dengan analisis deskriptif untuk mengukur kevalidan LKPD, pemodelan Rasch untuk mengukur kepraktisan LKPD, dan membandingkan kriteria ketuntasan minimal individu dan klasikal dari hasil post tes peserta didik untuk mengukur keefektifan LKPD. Hasil penelitian menunjukkan bahwa LKPD berbasis RME memenuhi kriteria valid dengan dominansi penilaian berada pada kategori baik, kriteria praktis dengan dominan respon peserta didik pada kategori praktis, serta efektif dengan persentase ketuntasan sebesar $87 \%$.
\end{abstract}

Kata kunci: LKPD; RME; konteks kemaritiman.

\begin{abstract}
The lack of use of teaching materials that are able to help learners to understand mathematics learning in schools causes the achievement of students' mathematical skills are still in the low category. The aims of this study is to develop a valid, practical and effective LKPD based on RME approach by using maritime context. This research is a type of Research and Development (R\&D) research with a limited ADDIE development model that are Analysis, Design, and Development (ADD) stage. Data in the study were collected by the test and questionnaire methods. The research instruments used were expert validation sheets, student questionnaire response sheets, and test sheets. Data was analyzed with descriptive analysis to measure the validity of LKPD, Rasch modeling to measure the practicality of LKPD, and compare individual and classical minimum completeness criteria from students' post-test results to measure the effectiveness of LKPD. The results showed that LKPD based on RME fulfilled valid criteria with the dominance of the assessment in the good category, practical criteria with the dominant response of students in the practical category, and effective with a percentage of completeness of $87 \%$.
\end{abstract}

Keywords: LKPD; RME; maritime context 


\section{JURNAL GANTANG. Oktober 2019; IV(2): 133 - 142 \\ p-ISSN. 2503-0671 \\ e-ISSN. 2548-5547}

\section{Pendahuluan}

Matematika merupakan salah satu ilmu pengetahuan yang diajarkan pada setiap jenjang pendidikan. Keberadaan ilmu pengetahuan ini begitu penting karena memiliki keterkaitan dengan lingkungan kehidupan sehari-hari. Hal ini sejalan dengan Permendikbud No. 58 Tahun 2016 tentang pedoman mata pelajaran matematika disebutkan bahwa pembelajaran matematika dilakukan untuk mencapai tujuan yang lebih ideal yaitu penguasaan kecakapan matematika yang diperlukan untuk memahami dunia disekitarnya.

Namun pada faktanya, masih banyak peserta didik yang kesulitan dengan berbagai persoalan matematika yang mereka dapatkan dalam materi pembelajaran. Hal ini terjadi karena minimnya pengetahuan peserta didik terhadap berbagai manfaat ilmu matematika yang erat kaitannya dengan kehidupan sehari-hari.

Salah satu faktor penyebabnya adalah pembelajaran yang dilaksanakan masih berorientasi pada pendidik di sekolah. Peserta didik terbiasa menerima langsung pengetahuan yang diberikan dan tidak ada proses rekonstruksi pengetahuan oleh peserta didik itu sendiri. Sehingga, suatu hal yang wajar apabila banyak peserta didik yang merasa kesulitan dengan mata pelajaran matematika. Sebagaimana yang diungkapkan oleh diungkapkan Ruseffendi (1984) bahwa matematika (ilmu pasti) bagi anak pada umumnya merupakan mata pelajaran yang tidak disenangi, kalau bukan sebagai mata pelajaran yang dibenci (Maulana 2009).

Dalam usaha mengatasi problematika tersebut, peran pendidik pada penyelenggaraan pembelajaran sangat penting. Pendidik harus mempersiapkan perangkat pembelajaran yang baik dan sesuai dengan materi serta kondisi peserta didik seperti bahan ajar. Bahan ajar adalah segala bahan baik informasi, alat maupun teks yang disusun secara sistematis yang menampilkan sosok utuh kompetensi yang akan dikuasai oleh peserta didik (Prastowo, 2015:17).

Bahan ajar dapat berupa bahan cetak dan bahan audio. Dalam pembelajaran matematika, bahan ajar yang paling relevan digunakan pendidik adalah bahan ajar cetak. Bahan ajar cetak dapat berupa handout, buku, modul, lembar kerja peserta didik, brosur, leaflet, dan wallchart (Purnomo, 2012:1). Pada umumnya, bahan ajar yang sering digunakan sebagai sumber belajar adalah buku.

Fakta dilapangan menunjukkan bahwa buku merupakan bahan ajar utama dalam memfasilitasi pembelajaran. Namun, sebagian besar peserta didik belum mampu memahami materi pembelajaran hanya melalui buku teks. Berdasarkan hasil wawancara peserta didik kelas XI IPA bahwa sebagian besar peserta didik menyebutkan buku teks sudah dapat memfasilitasi pembelajaran namun belum mampu membuat peserta didik secara langsung memahami materi pembelajaran. Oleh karena itu, dibutuhkan suatu bahan ajar lain yang dapat mendukung proses pembelajaran dan dapat meningkatkan daya minat dan pemahaman peserta didik.

Salah satu bahan ajar yang dapat memfasilitasi pembelajaran adalah Lembar Kerja Peserta Didik (LKPD). Menurut Prastowo (2015:204) LKPD merupakan suatu bahan ajar cetak yang berupa lembar-lembar kertas yang berisi materi, ringkasan, dan petunjuk-petunjuk pelaksanaan tugas pembelajaran yang mesti dikerjakan oleh peserta didik yang mengacu kepada kompetensi dasar yang harus dicapai. LKPD dapat digunakan oleh pendidik agar dapat menyesuaikan dengan kondisi peserta didik sebagai pembelajar. Pengembangan LKPD diharapkan dapat menjadi solusi dalam memfasilitasi serta menjadi sarana latihan bagi peserta didik untuk mampu memecahkan masalah matematika melalui penyisipan permasalahan yang berasal dari masalah nyata (Realistic).

Realistic mathematics education (RME) merupakan suatu pendekatan pembelajaran khusus pada bidang matematika. RME memiliki ciri khas yang dapat menjadikan peserta didik sebagai pembelajar aktif dan memudahkan peserta didik untuk memahami persoalan matematika secara nyata (Ahmad \& Nasution, 2018:86). Karakteristik RME dengan yang 
termuat dalam LKPD sebagaimana diungkapkan oleh Gravemeijer (1997) dalam Athar (2012) adalah (1) penggunaan konteks, (2) menghubungkan dengan instrumen, (3) kontribusi peserta didik, (4) kegiatan interaktif dan (5) keterkaitan antar topik matematika. Penggunaan karakteristik RME dalam desain bahan ajar LKPD bertujuan agar peserta didik dapat menggunakan pengalamannya, mengkonstruksi sendiri melalui pengetahuan sebelumnya yang ada hubungannya dengan kehidupan sehari-hari dan menjadikan pembelajaran lebih bermakna khususnya pada pembelajaran matematika (Hadi, 2017) .

Selain terdapat karakteristik RME, LKPD juga dapat dikembangkan dengan memuat konteks lingkungan alam sekitar, seperti konteks kemaritiman. Hal tersebut dapat dilakukan karena kondisi geografis wilayah Kepulauan Riau sebagian besar terdiri atas pulau-pulau besar dan kecil (Akhirman, 2017). Menurut Wiradnyana (2016), kemaritiman menyangkut aspek manusia, lingkungan alam dan biotanya. Jadi, secara umum kemaritiman dapat diartikan sebagai segala sesuatu yang berkenaan dengan laut meliputi aspek manusia, lingkungan alam dan biotanya.

Beberapa hasil penelitian menunjukkan bahwa perangkat pembelajaran yang berupa Rencana Pelaksanaan Pembelajaran (RPP) dan LKPD berbasis RME telah memenuhi kriteria kevalidan, kepraktisan (keterlaksanaan) dan keefektifan (Waluyo, Sa'dijah, \& Subanji, 2016:2300). Temuan Damayanti, Zulkarnain, \& Herlina (2019:21) juga menunjukkan bahwa produk berupa perangkat pembelajaran (RPP dan LKPD) matematika berbasis Realistic Matemathics Education (RME) pada materi lingkaran teruji kevalidan dan kepraktisannya.

Beberapa penelitian yang berkaitan tersebut menghasilkan produk yang teruji valid, praktis dan efektif. Namun, masalah realistik yang diangkat sebelumnya belum mengkaji pengembangan bahan ajar dengan masalah realistik yang berkonteks kemaritiman. Oleh karena itu, peneliti tertarik mengembangkan bahan ajar LKPD berbasis RME dengan konteks kemaritiman dengan rumusan masalah yaitu bagaimana pengembangan lembar kerja peserta didik berbasis RME dengan konteks kemaritiman yang valid, praktis, dan efektif. Selanjutnya, penelitian ini dilakukan dengan tujuan untuk mengembangkan lembar kerja peserta didik berbasis RME dengan konteks kemaritiman yang valid, praktis serta efektif.

\section{Metode Penelitian}

Penelitian ini menggunakan pendekatan Research and Development (R \& D) atau dikenal dengan penelitian pengembangan. Tujuan dilakukan penelitian ini adalah untuk mengembangkan produk berupa bahan ajar LKPD berbasis RME pada peserta didik SMA Kelas XI. Penelitian ini diujicobakan untuk mengetahui kevalidan, kepraktisan serta keefektifannya.

Penelitian ini menggunakan model pengembangan ADDIE yang dikembangkan Dick and Carey (1996), namun peneliti hanya menerapkan sebagian dari model tersebut yang terdiri atas tahapan Analysis, Design, Development (ADD). Hal ini dikarenakan pelaksanaan tahap implementasi memerlukan proses dan waktu yang lama. Serta uji coba bahan ajar harus disesuaikan dengan materi pembelajaran yang sedang berlangsung di sekolah.

Mulyatiningsih (2014:195) menyebutkan bahwa proses pengembangan memerlukan beberapa kali pengujian dan revisi sehingga meskipun prosedur pengembangan dipersingkat namun didalamnya sudah mencakup proses pengujian dan revisi maka produk yang dikembangkan mampu memenuhi ktiteria baik, teruji secara empiris dan tidak ada kesalahan lagi. Oleh karena itu, penelitian yang akan dilakukan hanya sampai pada tahap pengembangan.

a) Tahap Analisis (Analysis)

Tahap analisis dalam penelitian ini terdiri atas analisis kurikulum, analisis materi dan analisis kondisi peserta didik.

b) Tahap Desain (Design)

Tahap perancangan atau desain dilakukan untuk merancang produk LKPD sesudah melakukan tahap analisis. Tahap perencanaan yang dilakukan dengan merancang spesifikasi produk LKPD yang akan dikembangkan. 


\section{JURNAL GANTANG. Oktober 2019; IV(2): 133 - 142 \\ p-ISSN. 2503-0671 \\ e-ISSN. 2548-5547}

Perancangan spesifikasi produk menggunakan software Microsoft Word 2010 for windows.

c) Tahap Pengembangan (Development)

Tahap ini dilakukan pembuatan produk LKPD yang telah dirancang tampilan dan isinya menggunakan software yang telah ditentukan. Deskripsi langkah-langkah pembuatan produk LKPD seperti yang dikemukakan Prastowo (2015:214). Setelah pembuatan produk LKPD selesai dan telah melalui tahapan bimbingan dengan dosen pembimbing, maka produk yang dihasilkan diuji validitasnya oleh ahli materi, ahli bahasa dan ahli media untuk menentukan kelayakan sebelum dilakukan uji coba pada peserta didik. Langkah selanjutnya adalah uji coba produk LKPD secara terbatas dan uji lapangan. Hal ini bertujuan untuk memperoleh data kepraktisan dan keefektifan.

Uji coba produk dilakukan pada 33 peserta didik kelas XI IPA 2 SMAN 4 Tanjungpinang. Data dalam penelitian ini terdiri atas data kualitatif dan data kuantitatif. Data tersebut dikumpulkan melalui metode tes dan angket. Instrumen yang digunakan dalam penelitian ini adalah instrumen lembar validasi untuk mengumpulkan data kevalidan LKPD, angket respon peserta didik untuk mengumpulkan data kepraktisan LKPD dan lembar soal tes untuk mengumpulkan data keefektifan LKPD.

Analisis data yang dilakukan pada penelitian ini meliputi statistika deskriptif untuk menganalisis data kevalidan LKPD dengan mendeskripsikan penilaian yang diberikan oleh ahli materi, media dan bahasa. LKPD dikatakan valid apabila penilaian terakhir yang diberikan oleh masing-masing ahli minimal pada kategori baik.

Analisis data kepraktisan LKPD dengan menggunakan pemodelan rasch dengan melihat sebaran respon pada menu person map dan menghitung nilai pemisahan strata (Sumintono dan Widhiarso, 2015:85).

$$
H=\frac{[(4 \times \text { SEPARATION })+1]}{3}
$$

Tingkat kepraktisan produk yang dikembangkan dapat dilihat berdasarkan kecenderungan respon yang diberikan oleh responden melalui menu person item map.

Selanjutnya, analisis data keefektifan LKPD dengan membandingkan hasil post tes peserta didik dengan kriteria ketuntasan minimal (KKM) sekolah yaitu 72. Ketuntasan klasikal dihitung dengan rumus:

$$
\text { Ketuntasan }(p)=\frac{\sum \text { PD yang tuntas }}{\sum \text { PD yang mengikuti tes }} \times 100 \%
$$

Produk LKPD dikatakan efektif apabila minimal tingkat ketuntasan tes hasil belajar yang dicapai adalah kriteria efektif (Widoyoko, 2017:242) seperti yang ditunjukkan Tabel 1 di bawah ini.

Tabel 1. Kriteria ketuntasan klasikal

\begin{tabular}{ll}
\hline Persentase (\%) & Kriteria \\
\hline$p \leq 20$ & Tidak Efektif \\
\hline $20<p \leq 40$ & Kurang Efektif \\
\hline $40<p \leq 60$ & Cukup Efektif \\
\hline $60<p \leq 80$ & Efektif \\
\hline$p>80$ & Sangat Efektif \\
\hline
\end{tabular}

\section{Hasil dan Pembahasan}

Penelitian ini dilaksanakan di SMAN 4 Tanjungpinang. Subjek uji coba sebanyak 33 peserta didik kelas XI IPA 2 SMAN 4 Tanjungpinang. Hasil utama penelitian ini adalah LKPD berbasis RME dengan konteks kemaritiman. Adapun deskripsi tahapan pengembangan produk adalah sebagai berikut:

a) Tahap Analisis (Analysis)

Tahap analisis terdiri atas analisis kurikulum, analisis materi dan analisis kondisi peserta didik. Analisis kurikulum berisi pemetaan kompetensi dasar, indikator pencapaian kompetensi, dan tujuan pembelajaran. Kurikulum yang digunakan sekolah adalah kurikulum 2013 revisi 2017. Kompetensi dasar yang diperoleh adalah kompetensi dasar 3.6 Menggeneralisasi pola bilangan dan jumlah pada barisan Aritmetika dan Geometri dan 4.6 Menggunakan pola barisan aritmetika atau geometri untuk menyajikan dan menyelesaikan masalah. 
Analisis materi yang dipelajari peserta didik kelas XI IPA semester genap adalah barisan, limit fungsi, turunan dan integral tak tentu. Setelah dianalisis, topik barisan dipilih peneliti untuk dimuat dalam LKPD karena topik ini bisa direlevansikan dengan pendekatan RME. Selanjutnya, analisis kondisi peserta didik SMAN 4 Tanjungpinang. Berdasarkan hasil wawancara guru, ditemukan bahwa 1) kemampuan matematis peserta didik bervariasi setiap kelasnya. Ada yang baik, sedang dan kurang terkait kemampuan matematisnya. 2) Minat belajar matematika peserta didik juga bervariasi. Minat tersebut tergantung pada tingkat mudah atau sukarnya materi yang disampaikan. 3) Kesulitan-kesulitan yang sebagian besar dialami oleh peserta didik adalah kurang teliti dalam menghitung, kurang terlatih berfikir kritis dan sulit untuk menafsirkan persoalan matematika. 4) bahan ajar yang digunakan adalah LKS Tuntas dan buku Kemendikbud edisi revisi.

Berdasarkan hasil analisis kondisi peserta didik maka peneliti beranggapan bahwa kemampuan matematis peserta didik belum berkembang secara optimal dan bahan ajar yang digunakan masih berorientasi pada buku teks sehingga diperlukan suatu solusi yang dapat meningkatkan kompetensi peserta didik pada mata pelajaran matematika. Oleh karena itu, peneliti mengembangkan LKPD agar dapat menjadi wadah dalam memfasilitasi pembelajaran matematika.

b) Tahap Desain (Design)

Tahap selanjutnya dilakukan setelah tahap analisis adalah tahap perancangan spesifikasi produk LKPD. Spesifikasi produk LKPD terdiri atas tiga bagian utama yaitu bagian depan, bagian isi dan bagian penutup. Langkah perancangan spesifikasi produk LKPD mengadaptasi langkah pembuatan LKPD menurut Prastowo (2015:212).

Adapun komponen penyusun LKPD bagian depan yaitu halaman sampul depan, kata pengantar, daftar isi, dan tokoh matematika. Bagian isi terdiri atas pemetaan KD, IPK, dan tujuan pembelajaran, petunjuk belajar, materi pembelajaran, latihan soal, dan rangkuman. Serta bagian penutup terdiri atas daftar pustaka, biodata penulis dan halaman sampul belakang LKPD.

c) Tahap Pengembangan (Development)

Setelah merancang secara konseptual komponen penyusun LKPD, maka kegiatan selanjutnya adalah menyusun instrumen penelitian yang terdiri dari lembar validasi ahli, angket respon peserta didik dan pendidik dan soal tes.

Selain menyusun instrumen, pada tahap pertama dalam pengembangan dilakukan pembuatan LKPD berdasarkan rancangan yang telah disusun pada tahap desain. LKPD terdiri atas dua aktivitas yaitu aktivitas 1.1 Barisan Aritmatika dan aktivitas 1.2 Deret Aritmatika. LKPD dibuat juga dengan menyesuaikan karakteristik RME dari penggunaan konteks hingga keterkaitan antar topik.

LKPD yang telah disusun tersebut memasuki tahap kedua yaitu expert review yang terdiri atas ahli materi, ahli bahasa, dan ahli media. LKPD sebelum divalidasi dapat dilihat pada Gambar 1.
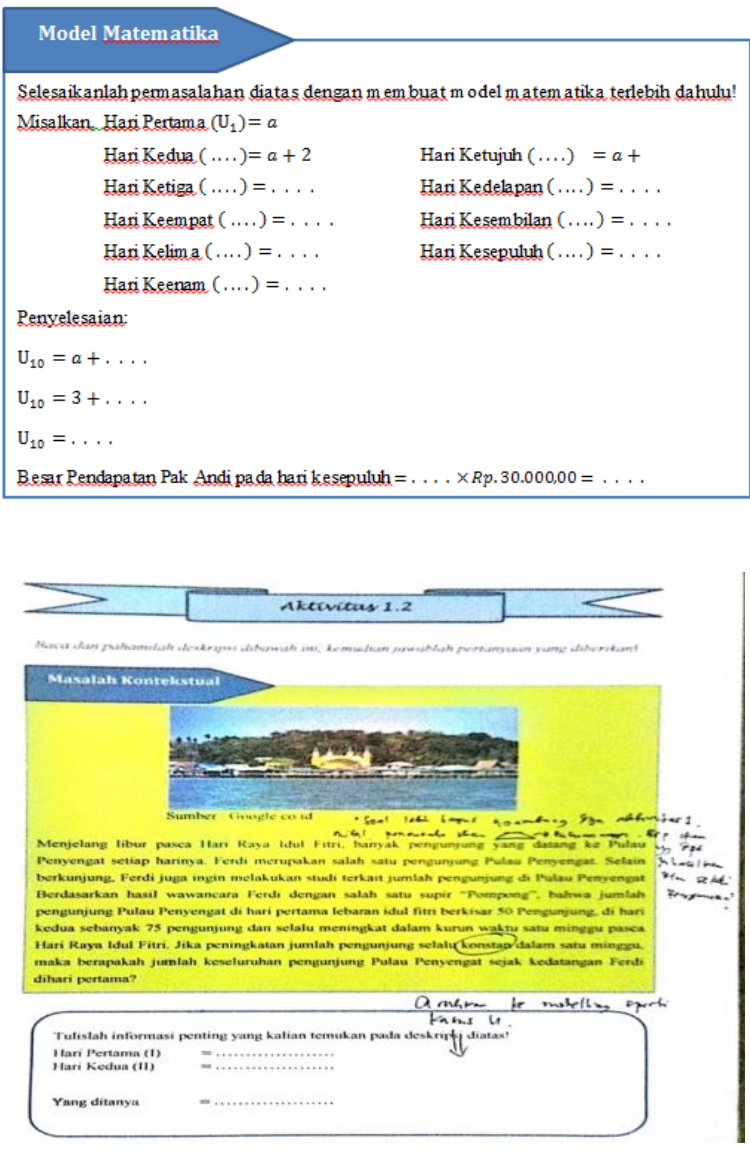

Gambar 1. LKPD sebelum revisi dari aspek materi 


\section{JURNAL GANTANG. Oktober 2019; IV(2): 133 - 142 \\ p-ISSN. 2503-0671 \\ e-ISSN. 2548-5547}

Penilaian dari aspek materi (konten) terdapat perbaikan yang cukup signifikan. Perbaikan tersebut terjadi pada komponen karakteristik RME yang belum tergambar jelas terutama pada bagian modeling. Perlu ditambahkan kolom untuk peserta didik mengeksplor terlebih dahulu jawabannya sendiri pada masalah kontekstual yang diberikan dan permasalahan pada aktivitas 1.2 sebaiknya disesuaikan dengan aktivitas 1.1. Perbaikan dari aspek materi dapat dilihat pada Gambar 1 dan 2. Penilaian yang diberikan oleh ahli materi yang terakhir dalam kategori baik.

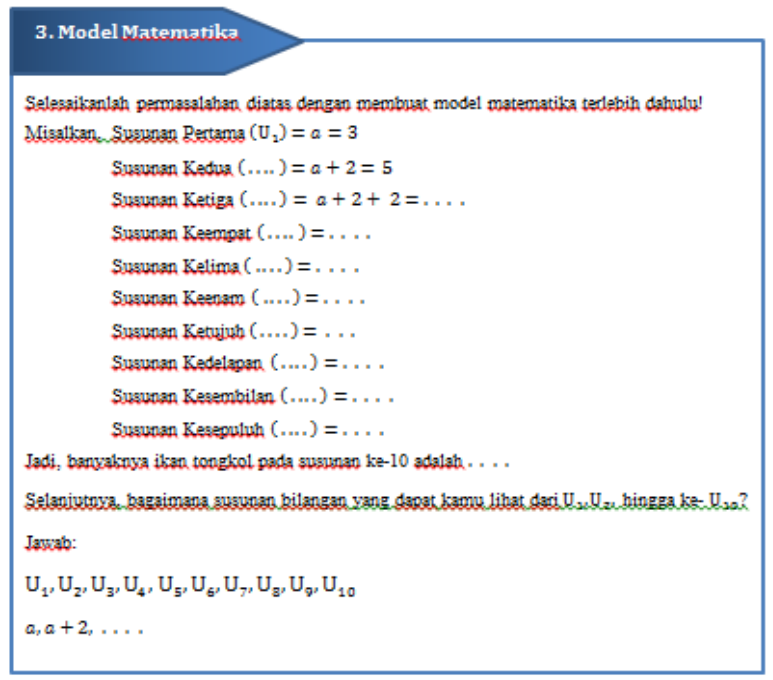

\section{Alktivitas 1.2}

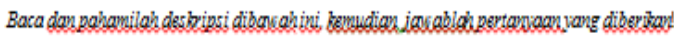

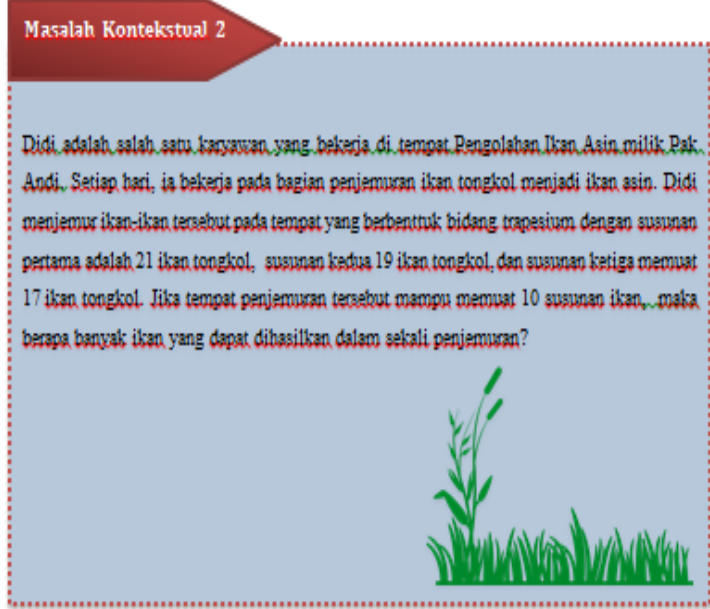

Gambar 2. LKPD setelah revisi dari aspek materi
Penilaian dari aspek bahasa cenderung pada redaksi kalimat yang terdapat pada soal latihan LKPD masih belum jelas sehingga sedikit sulit dipahami. Produk diperbaiki sesuai saran dari ahli. Perbaikan dari aspek bahasan dapat dilihat pada Gambar 3 dan 4. Setelah produk direvisi, penilaian yang diberikan ahli bahasa dominan dalam kategori sangat baik.

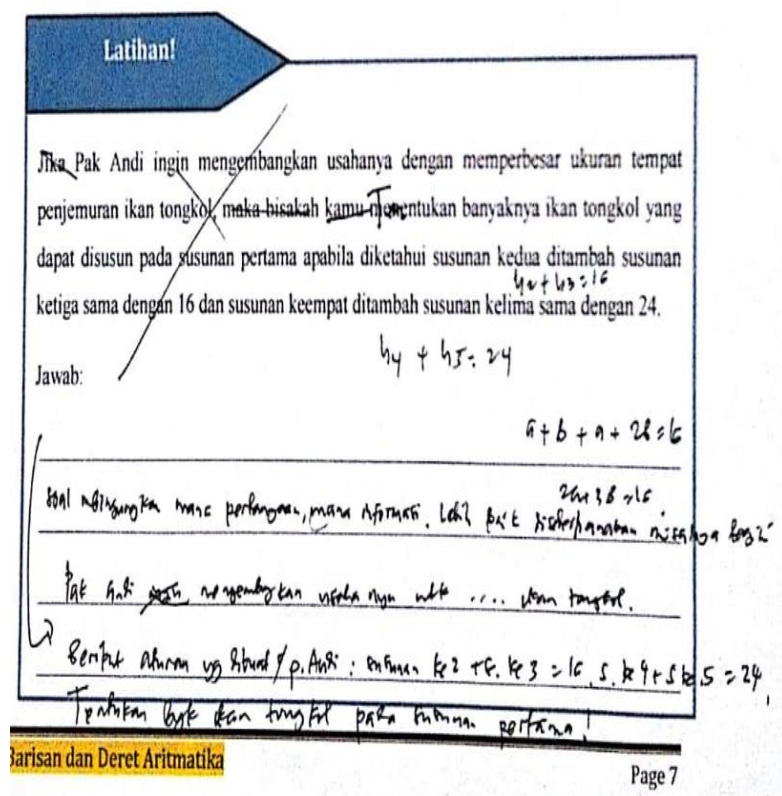

Gambar 3. LKPD sebelum revisi dari aspek bahasa

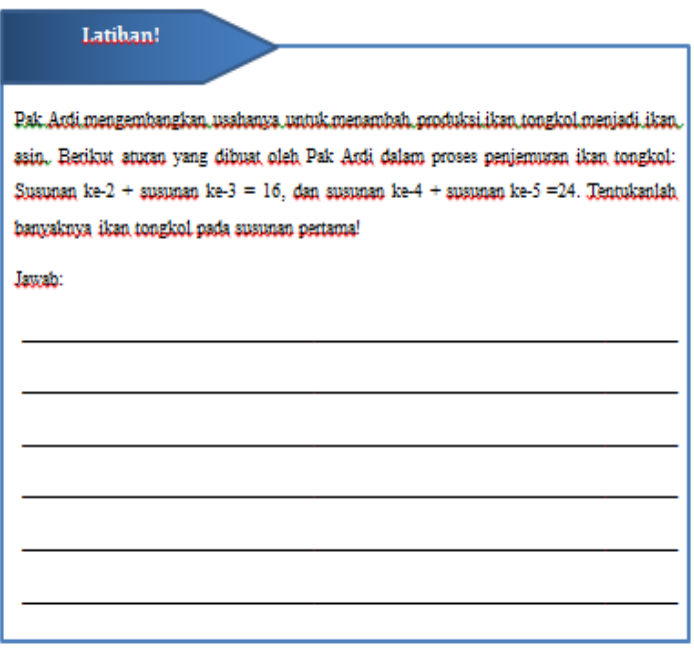

Gambar 4. LKPD setelah revisi dari aspek bahasa

Terakhir, aspek media tidak membutuhkan revisi yang besar dan hanya terdapat sebuah saran yaitu penambahan bagian sub cover pada tiap-tiap aktivitas yang terdapat dalam LKPD. Setelah produk direvisi, penilaian 
terakhir yang diberikan oleh ahli media dominan dalam kategori baik. Penilaian terakhir dari masing-masing ahli dapat dilihat pada Gambar 57.

\begin{tabular}{|c|c|c|c|c|c|}
\hline \multirow[b]{2}{*}{ No } & \multirow[b]{2}{*}{ Komponen } & \multirow{2}{*}{ Deskripsi } & \multicolumn{3}{|c|}{ Nilai } \\
\hline & & & \begin{tabular}{|l|l|}
1 & 2 \\
\end{tabular} & \begin{tabular}{|l|l}
3 & 4 \\
\end{tabular} & \begin{tabular}{l|l}
4 & 5 \\
\end{tabular} \\
\hline \multirow[t]{2}{*}{1} & \multirow[t]{2}{*}{$\begin{array}{l}\text { Kesesuaian } \\
\text { dengan KI dan KD }\end{array}$} & $\begin{array}{l}\text { 1) Lembar Kerja Peserta Didik sesuai dengan } \\
\text { kompetensi dasar pada kunkulum } 2013 \\
\text { revisi } 2017\end{array}$ & & $v$ & \\
\hline & & $\begin{array}{l}\text { 2) Indikator yang digunakan pada lembar } \\
\text { keja Peserta Didik sesuai dengan } \\
\text { kecapasan kompetensi dasar }\end{array}$ & & & $\checkmark$ \\
\hline \multirow[t]{4}{*}{2} & \multirow[t]{4}{*}{$\begin{array}{l}\text { Kebenaran } \\
\text { substansi materi } \\
\text { pembelajaran }\end{array}$} & $\begin{array}{l}\text { 3) Materi yang disajikan mula dan kasus } \\
\text { untuk penemuan konsep. latihan, dan } \\
\text { rangkuman }\end{array}$ & & & I \\
\hline & & $\begin{array}{l}\text { 4) Konsep yang disajikan sesuai dengan } \\
\text { konsep yang berlaku dalam materi barisan } \\
\text { dan deret antmatika }\end{array}$ & & $v$ & $\checkmark$ \\
\hline & & $\begin{array}{l}\text { 5) Contoh soal yang disajikan dalam Lembar } \\
\text { Kerja Peserta Didik berbentuk kontekstual }\end{array}$ & & & $\checkmark$ \\
\hline & & $\begin{array}{l}\text { 6) Gambar yang disajikan sesual dengan } \\
\text { materi }\end{array}$ & & & $\checkmark$ \\
\hline \multirow[t]{5}{*}{3} & \multirow{5}{*}{$\begin{array}{l}\text { Kesesuaian } \\
\text { dengan } \\
\text { Karakteristik } \\
\text { RMEE }\end{array}$} & $\begin{array}{l}\text { 7) Penyajıan maten dalam LKPD dimulaı } \\
\text { dengan suatu masalah (Konteks) }\end{array}$ & & & $\checkmark$ \\
\hline & & $\begin{array}{l}\text { 8) Masalah yang diberikan memungkinkan } \\
\text { peserta didik untuk melakukan pemodelan } \\
\text { matematika }\end{array}$ & & & $\checkmark$ \\
\hline & & $\begin{array}{l}\text { 9) Masalah yang diberikan dalam LKPD } \\
\text { mampu mengarahkan peserta didik untuk } \\
\text { berkontribusi dalam menyelesaikan } \\
\text { masalah }\end{array}$ & & & V \\
\hline & & $\begin{array}{l}\text { 10) Masalah dalam LKPD mampu } \\
\text { menstimulasi peserta didik untuk } \\
\text { berinteraktif menyampaikan argumen } \\
\text { dalam menyelesaikan permasalahan }\end{array}$ & & & $\checkmark$ \\
\hline & & $\begin{array}{l}\text { 11) LKPD dapat mengarahkan peserta didik } \\
\text { untuk menunjukkan keterkaitan topik yang } \\
\text { sedang dipelajari dengan topik matematika } \\
\text { lainnya }\end{array}$ & & & $\checkmark$ \\
\hline 4 & \begin{tabular}{|l|} 
Konteks \\
Kemaritiman
\end{tabular} & $\begin{array}{l}\text { 12) Permasalahan dalam LKPD memuat } \\
\text { konteks profesi kelautan sebagai salah satu }\end{array}$ & & & $\checkmark$ \\
\hline
\end{tabular}

Gambar 5. Penilaian dari aspek materi

\begin{tabular}{|c|c|c|c|c|c|c|}
\hline Y. & \multirow{2}{*}{ Komponen } & \multirow{2}{*}{ Deskripsi } & \multicolumn{4}{|c|}{ Nilai } \\
\hline No & & & \begin{tabular}{l|l}
12 \\
\end{tabular} & 3 & & \\
\hline \multirow[t]{5}{*}{1} & \multirow[t]{5}{*}{ Keterbacaan } & $\begin{array}{l}\text { 1) Kalimal pada kata pengantar sangat jelas } \\
\text { dan mudah dipahami }\end{array}$ & & & $\checkmark$ & \\
\hline & & $\begin{array}{l}\text { 2) Kalımat pada petunjuk pembelajaran } \\
\text { sangat jelas dan mudah dipahamı }\end{array}$ & & & $v$ & \\
\hline & & $\begin{array}{l}\text { 3) Kalimat pada tujuan pernbelayaran yang } \\
\text { disampaikan sesuai dengan ketercapaian } \\
\text { indikator }\end{array}$ & & & $v$ & \\
\hline & & $\begin{array}{l}\text { 4) Keterbacaan kalimat pada setiap isi mater } \\
\text { yang disampaikan sangat mudah dipahami }\end{array}$ & & & $v$ & \\
\hline & & $\begin{array}{l}\text { 5) Keterbacann kalımat pada setiap soal yang } \\
\text { dibenkan sangat mudah dipahamı }\end{array}$ & & & $v$ & \\
\hline 2 & $\begin{array}{l}\text { Kejelasan } \\
\text { Informasi }\end{array}$ & $\begin{array}{l}\text { 6) Kejelasan kalimat pada isi } \\
\text { menginformasikan permasalahan } \\
\text { kehidupan schari-hari }\end{array}$ & & & & $\checkmark$ \\
\hline \multirow[t]{4}{*}{3} & \multirow[t]{4}{*}{$\begin{array}{l}\text { Kesesuaian } \\
\text { dengan Kaidah } \\
\text { Bahasa Indonesia }\end{array}$} & $\begin{array}{l}\text { 7) Ketepatan kalımat yang digunakan pada isi } \\
\text { materi yang disampakan dengan tetap } \\
\text { mengikuti tata kalımat Bahasa Indonesia }\end{array}$ & & & $\checkmark$ & \\
\hline & & $\begin{array}{l}\text { 8) Tata kalimat yang digunakan untuk } \\
\text { menyampakan matei mengacu kepada } \\
\text { kaidah Bahasa Indonesia yang baik dan } \\
\text { benar }\end{array}$ & & & $v$ & \\
\hline & & $\begin{array}{l}\text { 9) Kalimat yang digunakan pada LKPD } \\
\text { sesuai dengan kamus besar Bahasa } \\
\text { Indonesia yang telah baku digunakan } \\
\text { dalam materi barisan dan deret aritmatika }\end{array}$ & & & $v$ & \\
\hline & & $\begin{array}{l}\text { 10) Ejaan yang digunakan mengacu kepada } \\
\text { pedoman ejaan yang disempurnakan }\end{array}$ & & & $v$ & \\
\hline \multirow[t]{2}{*}{4} & \multirow[t]{2}{*}{$\begin{array}{l}\text { Penggunaan } \\
\text { Bahasa }\end{array}$} & $\begin{array}{l}\text { 11) Bahasa yang digunakan pada LKPD } \\
\text { mengacu kepada kesederhanaan dan } \\
\text { pemahaman peserta didik }\end{array}$ & & & & $v$ \\
\hline & & $\begin{array}{l}\text { 12) Penggunaan bahasa sangat konsisten pada } \\
\text { bagian-bagian LKPD }\end{array}$ & & & $\checkmark$ & \\
\hline 5 & \begin{tabular}{|l|} 
Konteks \\
Kemaritiman
\end{tabular} & $\begin{array}{l}\text { 13) Bahasa yang digunakan dalam aspek } \\
\text { profesi kelautan memiliki koherensi yang } \\
\text { baik satu sama lain }\end{array}$ & & & $\checkmark$ & \\
\hline
\end{tabular}

Gambar 6. Penilaian dari aspek materi

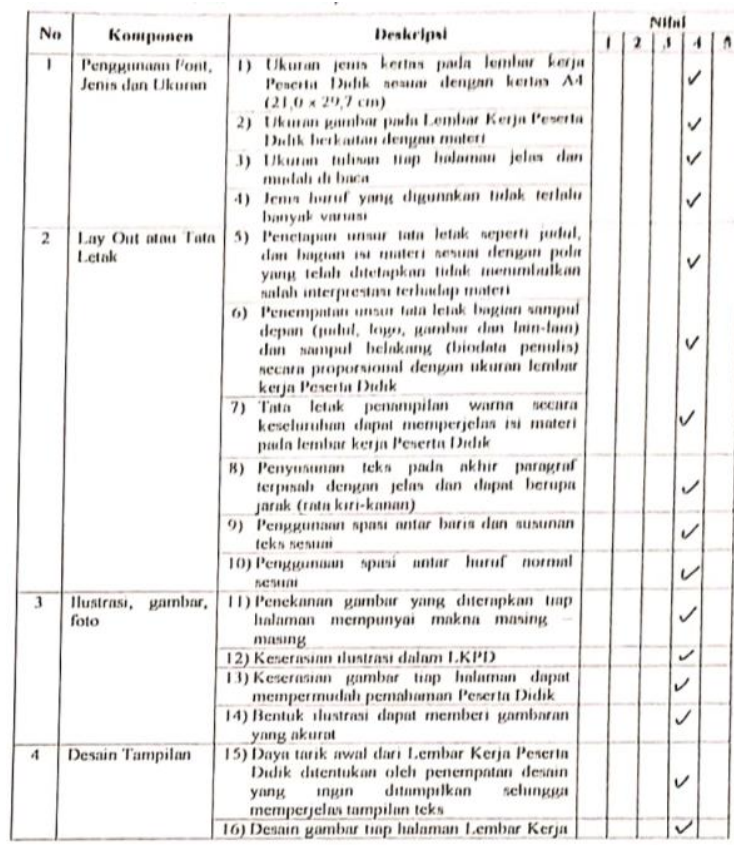

Gambar 7. Penilaian dari aspek materi

Secara keseluruhan, penilaian kualitas produk LKPD berbasis RME dari aspek materi, aspek bahasa dan aspek media berada kategori baik sehingga memenuhi kriteria valid. Oleh karena itu, LKPD layak diujicobakan pada subjek penelitian.

Tahap ketiga adalah uji coba produk. Uji coba produk terdiri dari uji coba terbatas dan uji coba lapangan. Uji coba terbatas dilakukan pada sekelompok peserta didik yang heterogen di kelas XI IPA 1. Hasil uji coba terbatas menunjukkan bahwa peserta didik dapat memahami materi, pertanyaan dan redaksi kalimat yang terdapat dalam LKPD, serta dapat menyelesaikan permasalahan yang terdapat dalam LKPD.

Setelah uji coba terbatas, maka LKPD siap diuji coba lapangan. Uji coba ini dilakukan pada 33 peserta didik kelas XI IPA 2 SMAN 4 Tanjungpinang. Uji coba lapangan dilakukan sebanyak 3 kali pertemuan yang terdiri dari 2 kali uji coba dan 1 pertemuan post tes. Akhir pembelajaran diberikan angket respon peserta didik dan pendidik serta soal post tes.

Data kepraktisan dianalisis dengan menggunakan aplikasi winstep. Adapun hasil yang ditunjukkan melalui pemodelan rasch dapat dilihat pada Gambar 7. 
JURNAL GANTANG. Oktober 2019; IV(2): 133 - 142

p-ISSN. 2503-0671

e-ISSN. 2548-5547

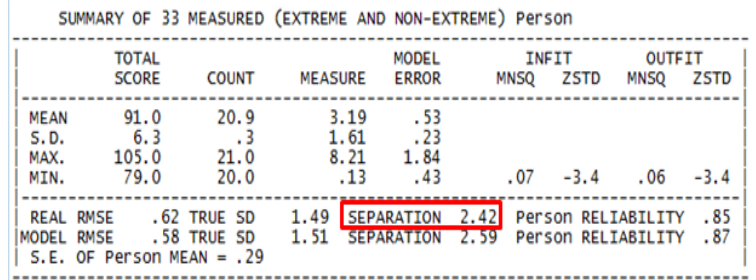

Gambar 7. Nilai separation angket respon peserta didik

Hasil indeks Separation Person yang didapatkan berdasarkan Gambar 5 ialah sebesar 2,42. Dengan indeks separation 2,42, maka strata responden dalam penelitian ini sebesar 3,56 dibulatkan menjadi 4, yang bermakna bahwa responden dibagi menjadi 4 kelompok praktikalitas LKPD yaitu tidak praktis, kurang praktis, praktis dan sangat praktis. Cara melihat frekuensi dari masing-masing kelompok dapat menggunakan menu Person Item Map. (Sumintono \& Widhiarso, 2015:85).

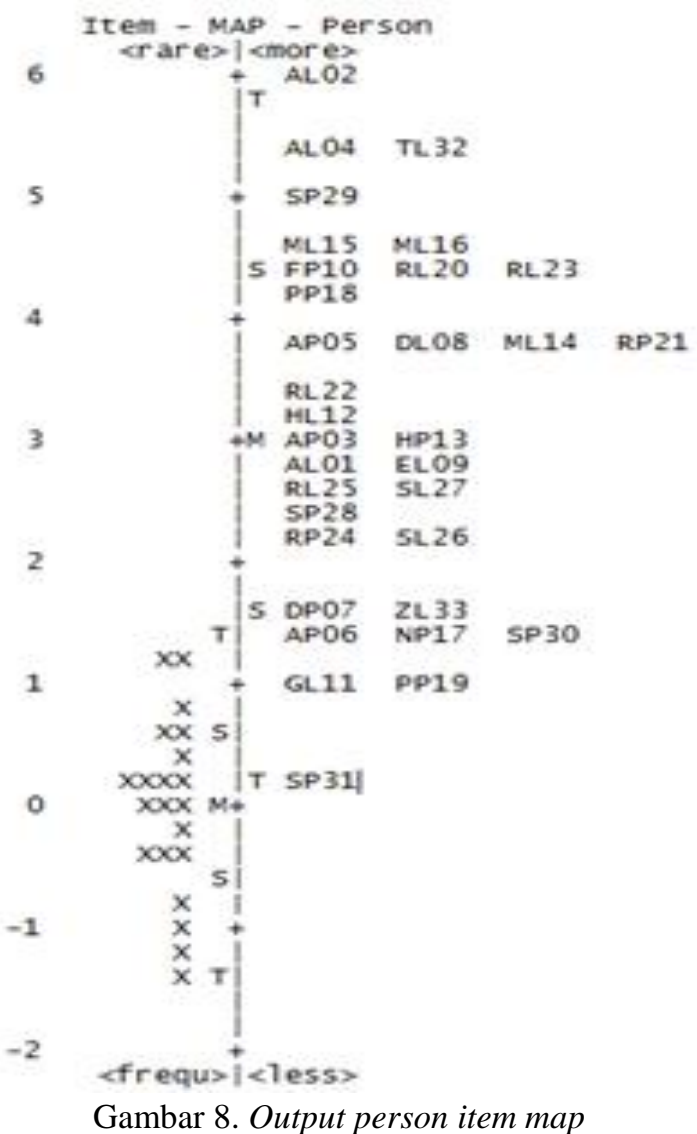

Pengelompokkan tingkat praktikalitas LKPD dan frekuensi dari masing-masing kelompok dapat dilihat pada Tabel 2 .
Tabel 2. Tingkat praktikalitas LKPD dengan person item map

\begin{tabular}{lcc}
\hline $\begin{array}{c}\text { Tingkat } \\
\text { Praktikalitas }\end{array}$ & $\begin{array}{c}\text { Interval Nilai } \\
\text { logit }\end{array}$ & $\begin{array}{c}\text { Frekuensi } \\
\text { PD }\end{array}$ \\
\hline Tidak Praktis & $-2<P<0$ & 0 \\
\hline Kurang Praktis & $0<P<2$ & 8 \\
\hline Praktis & $2<P<4$ & 15 \\
\hline Sangat Praktis & $4<P<6$ & 10 \\
\hline
\end{tabular}

Keterangan: $\mathrm{P}=$ Person / Peserta Didik

Berdasarkan Tabel 5, tingkat praktikalitas produk LKPD termasuk kategori praktis karena peserta didik dominan memberikan tanggapan kepraktisan LKPD dalam kategori praktis.

Hasil uji keefektifan LKPD pada pertemuan ketiga materi barisan dan deret aritmatika dapat dilihat pada Tabel 3 .

Tabel 3. Hasil tes peserta didik kelas XI IPA 2 SMAN 4 Tanjungpinang

\begin{tabular}{lccc}
\hline Ketuntasan & $\begin{array}{c}\text { Jumlah } \\
\text { PD }\end{array}$ & Persentase & $\begin{array}{c}\text { Rata- } \\
\text { rata } \\
\text { Nilai }\end{array}$ \\
\cline { 1 - 3 } Tuntas & 27 & $87 \%$ & 81,4 \\
\hline Tidak Tuntas & 4 & $13 \%$ & \\
\hline
\end{tabular}

Secara klasikal, ketuntasan yang diperoleh adalah 87\% yang mana menurut Widoyoko (2017:242) termasuk dalam kriteria sangat efektif. Hasil tersebut menunjukkan bahwa pembelajaran dengan menggunakan LKPD berbasis RME dengan konteks kemaritiman yang dikembangkan sangat efektif.

Berdasarkan hasil penelitian yang telah ditemukan dengan teknik analisis data yang dilakukan maka pada pembahasan penelitian dapat ditarik kesimpulan bahwa penilaian kualitas LKPD berbasis RME dengan konteks kemaritiman yang dikembangkan dilihat dari aspek validitas, praktikalitas dan efektifitas. Dari ketiga aspek penilaian kualitas LKPD diperoleh bahwa LKPD berbasis RME dengan konteks kemaritiman termasuk kategori valid, praktis dan efektif.

Validitas LKPD berbasis RME dengan konteks kemaritiman diukur melalui instrumen lembar validasi ahli materi, ahli bahasa dan ahli media. Berdasarkan hasil yang diperoleh menunjukkan bahwa LKPD yang dikembangkan 
terkategori valid dan layak untuk diuji coba di lapangan.

Hal ini dipandang wajar karena LKPD yang dikembangkan dapat memenuhi kriteria penilaian yang ditetapkan. LKPD sesuai dengan kondisi peserta didik karena sudah melalui tahapan analisis kurikulum. Sajian materi dalam LKPD dikemas dalam bentuk yang menarik. Tingkat keterbacaan dan kalimat-kalimat yang disajikan telah disesuaikan dengan kaidah Bahasa Indonesia. Selain itu, desain tampilan, penggunaan gambar, dan desain tata letak yang dapat memberikan daya tarik bagi peserta didik untuk belajar.

LKPD yang dikembangkan masuk dalam kategori praktis karena dominan respon yang diberikan peserta didik terdapat pada interval praktis. Beberapa hal yang mendukung LKPD praktis adalah pertama, segi daya tarik yang mana LKPD berbasis RME dengan konteks kemaritiman didesain dengan tampilan cover dan isi yang menarik. Kedua, segi penggunaan yang mana LKPD dapat memudahkan peserta didik dalam menemukan konsep barisan dan deret aritmatika. LKPD disusun dengan daftar pertanyaan yang dapat mengarahkan peserta didik dalam mengkonstruksi pengetahuan yang dimilikinya. Ketiga dari segi waktu yang digunakan dimana LKPD yang diuji coba setiap pertemuan sesuai dengan alokasi waktu yang diberikan. Oleh karena itu, LKPD berbasis RME dengan konteks kemaritiman wajar diberikan respon yang positif oleh peserta didik sehingga termasuk dalam kategori praktis.

LKPD yang dikembangkan juga sangat efektif dengan persentase $87 \%$. Kriteria tersebut dapat diperoleh karena pembelajaran yang dilaksanakan selama dua kali pertemuan telah menyesuaikan dengan rancangan pembelajaran yang berkarakteristik RME, sehingga dapat memberikan efek positif bagi peserta didik.

Sejalan dengan hal tersebut, penelitian Sari, Amir, dan Risnawati (2017:73) menunjukkan bahwa hasil pengembangan LKS berbasis pendekatan RME untuk memfasilitasi kemampuan representasi matematis dinyatakan valid, praktis dan efektif. Andari dan Komsiatun (2018:159) juga menunjukkan lembar kerja siswa
(LKS) berbasis RME yang dikembangkan valid, praktis dan efektif untuk meningkatkan kemampuan matematis siswa.

\section{Kesimpulan}

Berdasarkan hasil penelitian dan pembahasan pengembangan LKPD berbasis RME dengan konteks kemaritiman diperoleh bahwa LKPD yang dikembangkan memenuhi kriteria valid dengan penilaian yang diberikan oleh masing-masing ahli dalam kategori baik. LKPD yang dikembangkan juga memenuhi kriteria praktis dari respon peserta didik dengan dominan respon peserta didik pada person item map dalam kategori praktis. LKPD yang dikembangkan juga memenuhi kriteria sangat efektif dengan persentase ketuntasan sebesar $87 \%$.

\section{Referensi}

Ahmad, M., \& Nasution, D. P. (2018). Analisis kualitatif kemampuan komunikasi matematis siswa yang diberi pembelajaran matematika realistik. Jurnal Gantang, 3(2), 8395.doi:https://doi.org/10.31629/jg.v3i2.4 71

Akhirman. (2017). Buku ajar kewirausahaan berbasis kearifan lokal. Tanjungpinang: UMRAH PRESS.

Andari, T., \& Komsiatun, E. (2018). Pengembangan lks berbasis pendekatan realistic mathematics education untuk meningkatkan kemampuan matematis siswa. Aksioma, 7(1), 155-160. http://ejournal.uin-suska.ac.id/index.php/

Athar, G. A. (2012). Pengembangan

pembelajaran matematika dengan pendekatan pendidikan matematika realistik (PMR) berbasis budaya cerita rakyat melayu Riau. UNY, 12. http://eprints.uny.ac.id/7570/

Damayanti, V.O., Zulkarnain, \& Herlina, S. (2019). Pengembangan perangkat pembelajaran matematika berbasis realistic matemathics education (rme) pada materi lingkaran di kelas viii smp negeri 6 siak hulu. AKSIOMATIK: Jurnal 
JURNAL GANTANG. Oktober 2019; IV(2): 133 - 142

p-ISSN. 2503-0671

e-ISSN. 2548-5547

Penelitian Pendidikan Dan

Pembelajaran Matematika, 7(2), 15-21

Hadi, S. (2017). Pendidikan matematika realistik

(1st ed). Depok: PT Rajagrafindo Persada

Maulana. (2009). Pembelajaran matematika yang

konstruktif di sekolah dasar.

https://anzdoc.com/queue/pembelajaran-

matematika-yang-konstruktif-di-sekolah-

dasar-1-.html

Mulyatiningsih, E. (2014). Metode penelitian terapan bidang pendidikan (3rd ed). Bandung: Alfabeta

Prastowo, A. (2015). Panduan kreatif membuat bahan ajar inovatif ( 7 th ed). Yogyakarta: Diva Press

Purnomo, D. (2012). Pengembangan bahan ajar matematika sebagai sarana pengembangan kreativitas berpikir. AKSIOMA : Jurnal Matematika Dan Pendidikan Matematika, 2(1). http://journal.upgris.ac.id/index.php/aksi oma/article/view/43

Sari, R. M., Amir, Z., \& Risnawati. (2017). Pengembangan lembar kerja siswa (lks) berbasis pendekatan realistic mathematic education (rme) untuk memfasilitasi kemampuan representasi matematis siswa smp. Jurnal Formatif, 7(11), 66-74. http://journal.lppmunindra.ac.id/index.ph p/Formatif/article/view/1108

Sumintono, B., \& Widhiarso, W. (2015). aplikasi pemodelan rasch pada assesment pendidikan. Cimahi: Trim Komunikata

Waluyo, E., Sa'dijah, C., \& Subanji. (2016). Pengembangan rpp dan lkpd berbasis realistic mathematics education dengan memerhatikan beban kognitif siswa materi bangun ruang sederhana kelas iv sd. Jurnal Pendidikan, 1(12), 2300-2306

Widoyoko, E. P. (2017). Evaluasi program pembelajaran (9th ed). Yogyakarta: Pustaka Pelajar

Wiradnyana, K. (2016). Aspek-aspek kemaritiman di dataran rendah dan dataran tinggi dari masa mesolitik hingga tradisi megalitik. Berkala Arkeologi Sangkhakala, $\quad 19(1), \quad 28-42$. http://sangkhakala.kemdikbud.go.id/inde x.php/SBA/article/view/21 